International Research Journal of Management, IT \& Social Sciences
Available online at https://sloap.org/journals/index.php/irjmis/
Vol. 6 No. 6, November 2019, pages: 164 171
ISSN: 2395-7492
https://doi.org/10.21744/irjmis.v6n6.782

\title{
Regional Financial Performance Mediates the Effect of Regional Balance Funds and Expenditures on Economic Growth
}

\author{
Siktania Maria Dilliana ${ }^{a}$ \\ Gayatri $^{b}$ \\ Ni Made Dwi Ratnadi ${ }^{c}$ \\ I Gde Ary Wirajaya ${ }^{\mathrm{d}}$
}

Article history:

Received: 09 July 2019

Accepted: 30 September 2019

Published: 31 October 2019

\section{Keywords:}

balance funds;

economic growth;

effect;

financial performance;

regional expenditure;

\begin{abstract}
This study aims to obtain empirical evidence about the balance funds and regional expenditure on economic growth with regional financial performance as a mediating variable. The results showed that the balance fund did not affect the financial performance of the region with a result of 0.054 indicating that the balance fund received by the regional government increased or decreased could not affect the regional financial performance. Regional expenditure has a negative effect on regional financial performance with a result of 0.006 indicating that the allocation of indirect expenditure is higher than the direct expenditure allocation. Balancing funds have a positive effect on economic growth with a result of 0.031 indicating that the amount of general allocation funds, special allocation funds, and profit-sharing funds has increased so that economic growth also increases. Regional expenditure has a positive effect on economic growth with a result of $0.020^{\prime}$ indicating that there is infrastructure development undertaken to encourage regional economic growth. Regional financial performance has a positive effect on economic growth with a result of 0.009 indicating that regional capability is getting better based on the results of the ratio of independence, effectiveness, and efficiency. Regional financial performance is able to mediate balance funds against economic growth with a result of 324.6869 indicating that the greater the balance funds obtained will improve the financial performance of local governments and regional economic growth, while regional financial performance is not able to mediate regional spending on economic growth with results 105,3030 shows that there has been an increase in the allocation of regional expenditure budgets, but local governments are less focused on leading sectors.
\end{abstract}

${ }^{a}$ Udayana University, Denpasar, Indonesia

${ }^{\mathrm{b}}$ Udayana University, Denpasar, Indonesia

${ }^{\text {c } U d a y a n a ~ U n i v e r s i t y, ~ D e n p a s a r, ~ I n d o n e s i a ~}$

${ }^{\mathrm{d}}$ Udayana University, Denpasar, Indonesia 
Author correspondence:

Siktania Maria Dilliana,

Faculty of Economics and Business,

Udayana University, Denpasar, Indonesia.

Email address: rhyaathania30@gmail.com

\section{Introduction}

Economic growth is an indicator to find out how much success a country's economic development is and determines the existence of further development policies (Putong, 2013). The basic concept of macroeconomic indicators used in measuring economic growth is the gross regional domestic product. One of the goals of the local government is economic growth which increases every year. Sikka Regency as an autonomous region that has the authority to organize government and development and provide services to the community in Sikka Regency. Gross regional domestic product is a tool that can be used to measure the economic growth of a region. By comparing regional gross domestic product between years, it can be seen that economic growth is a result of economic activity during the time period in the region.

Agriculture, forestry, and fisheries are the leading sectors of Sikka Regency that play an active role in economic growth, but in reality, the role of these three factors has gradually declined (www.cendananews.com). From the existing data on gross regional domestic products and seen from the current conditions, it can be concluded that regional income and expenditure owned by the local government of Sikka Regency have not been used optimally as measured by the rate of economic growth. Regional balancing and spending funds have a large role as a source of development funding and are ultimately able to drive economic growth in the region. The amount of balance funds received by the local government of Sikka Regency fluctuates but tends to increase and regional expenditure allocations increase every year.

These fluctuations, but tended to increase, from the balance of funds shows that Sikka Regency is not becoming more independent, but is increasingly dependent on the central government. This proves that the regions lack seriousness in exploring and optimizing regional assets and potential and rely more on equalization funds. Balancing funds from the central government affect regional financial performance which can be explained using stewardship theory. This theory assumes a strong relationship between organizational success and owner satisfaction. Steward will protect and maximize the organization's wealth with company performance so that the utility function will increase.

Stewardship theory illustrates the relationship between transfer funds received by local governments has a tendency to be managed properly and correctly so that it can improve regional financial performance and will have an impact on increasing economic growth. The allocation of regional expenditure prepared by the regional government as a steward is then approved by the regional people's representative council as the principal, which must be prioritized for the purpose of increasing the economic growth of a region. Stewardship theory describes the relationship of the allocation of regional spending on the regional financial performance that will have an impact on increasing regional economic growth both directly and indirectly.

Several studies that are relevant to this research have been carried out, such as Pratini \& Utama (2016), which shows the relationship of local own-source revenue, capital expenditure and non-linear general allocation funds that is positive and significant to the economic growth of West Kalimantan. Kusumawati \& Wiksuana (2018), who found that local revenue and special allocation funds had a positive effect on economic growth, while general allocation funds and revenue sharing funds had a negative effect on economic growth. Astuti (2015), shows the ratio of independence and efficiency ratios have a significant positive effect on economic growth, while the effectiveness ratio does not significantly influence economic growth. This research has never been done in Sikka Regency. Therefore, it is very important to do so that the level of regional income and expenditure is optimally distributed.

Based on the background described above, the purpose of this study is to analyze the effect of regional balance funds and expenditure on regional financial performance, to analyze the effect of balance funds, regional expenditure and regional financial performance on economic growth, to obtain empirical evidence about the ability of performance Regional finance mediates the effect of regional balance funds and spending on economic growth.

\section{Literature Review and Hypothesis}

The grand theory used in this study is the stewardship theory (Donalson \& Davis, 1991). The implication of the Stewardship theory for this research is that it can explain the existence of local government as an institution that can

Dilliana, S. M., Gayatri, G., Ratnadi, N. M. D., \& Wirajaya, I. G. A. (2019). Regional financial performance mediates the effect of regional balance funds and expenditures on economic growth. International Research Journal of Management, IT and Social Sciences, 6(6), 164-171. https://doi.org/10.21744/irjmis.v6n6.782 
be trusted to accommodate the aspirations of the community, can provide good services to the public, be able to make financial responsibilities mandated to it, so that economic objectives are met and community welfare can be achieved to the maximum. The hypothesis is as follows:

Balance funds are funds sourced from the state expenditure budget allocated to the regions. Stewardship theory assumes a strong relationship between organizational success and owner satisfaction. The government will try its best to run the government to achieve the government's goal of improving people's welfare. The high amount of balance funds received by local governments will be able to be an adequate source of funding for local governments so as to create a good financial performance. Sidik (2002), provides empirical evidence that a balancing fund is an educational tool for local government as an effort to collect local revenue. Based on the description, the hypothesis proposed is:

H1: Balancing funds have a positive effect on regional financial performance.

Absorption or realization of a large regional budget should be a reflection of a large amount of infrastructure and facilities being built. So that more development will improve services to the community so that regional performance will be better. The implication of this research related to the stewardship theory is that the local government acts as a steward, the recipient of the mandate to use regional revenues for the benefit of regional development towards a more financially independent direction. Research by Mustikarini \& Fitriasari (2012), provides empirical evidence that regional spending has proved to have a significant positive effect. Based on the description, the hypothesis proposed is:

H2: Regional expenditure has a positive effect on regional financial performance.

Balance funds are the main source of revenue for the region. The allocation of general allocation funds is intended to finance regional routine expenditure to increase regional economic growth. Likewise with profit-sharing funds that play a role in economic growth. Because the revenue sharing fund is also a source of revenue in the regional budget and increase. Special allocation funds are funds provided by the central government which is allocated to finance development activities that are special in nature. In the stewardship theory, the regional government as the recipient of the mandate to use balance funds for the benefit of regional development so as to increase regional economic growth. Indarto \& Ayu (2011), namely central government spending realized in the regions have a positive effect on economic growth. Based on the description, the hypothesis proposed is:

H3: Balancing funds have a positive effect on economic growth.

Regional expenditure consisting of direct expenditure and indirect expenditure is a form of government expenditure. An increase in regional expenditure consisting of indirect and direct expenditure will have an impact on the increase in the percentage of gross regional domestic product. Steward theory is guided by the fact that there is greater utility in cooperative action and that action is considered rational action that can be accepted, for example by carrying out cost efficiency. When the regional budget is managed well, regional economic growth will increase and vice versa. Nuryani et al., (2018), shows that indirect and direct expenditure has a significant positive effect on economic growth. Based on the description, the hypothesis proposed is:

H4: Regional expenditure has a positive effect on economic growth.

The implementation of regional autonomy requires each region to be more independent. This independence is indicated by an increase in regional financial performance which is expected to improve the quality of life of the community and economic growth. In stewardship theory, stewards will protect and maximize organizational wealth with company performance, so that the utility function will be maximized. This research is in line with the research of Nisa (2017); Mahaputra \& Putra (2014); and Suryaningsih et al., (2015). Based on the description, the hypothesis proposed is:

H5: Financial performance in the form of regional financial independence ratio, effectiveness ratio, and efficiency ratio has a positive effect on economic growth.

The greater the balance of funds obtained from the central government to regional governments, it can be an adequate source of funding for local governments so that they can guarantee the smooth operation of regional government operations and be able to create a good financial performance. The greater the costs and the better the financial performance carried out, the greater the development of public infrastructure that can be done and this will directly lead to increased regional economic growth. Stewardship theory explains that the government will act as a steward, the recipient of the mandate to use regional revenue for the benefit of regional development towards a more financially independent direction. Based on the description, the hypothesis proposed is: 
H6: Financial performance is able to mediate the effect of balanced funds on economic growth.

The higher level of local government expenditure reflects the higher level of services provided to the community. The higher the level of service provided to the community, the higher the performance value of the local government. And if the regional government sets a high regional budget to build facilities and infrastructure in a region, this regional budget expansion policy will boost regional economic growth and the value of regional financial performance will be better. According to Hadi et al., (2018), Stewardship theory assumes a strong relationship between organizational success and owner satisfaction. Based on the description, the hypothesis proposed is:

H7: Financial performance is able to mediate the effect of regional spending on economic growth.

\section{Materials and Methods}

The population in this study is the Sikka Regency Regional Asset Management and Financial Services Office. In this study, the financial statement data used is quantitative data. The data source used in this study is secondary data. The data collection method used in this study is to conduct a non-participant observation method. The data analysis technique used to analyze data is path analysis. In the path analysis, a single test is also performed to determine the indirect effect of the independent variables on the dependent variable. However, before conducting a regression analysis, the classical assumption test and the model feasibility test are conducted to determine whether the regression model is made free of bias and is suitable for use in the analysis.

\section{Results and Discussions}

Path analysis method aims to determine the direct effect of independent variables on the dependent variable:

Table 2

Direct effect

\begin{tabular}{lccccc}
\hline Variables & B & $\begin{array}{c}\text { Unstandardized } \\
\text { Coefficients } \\
\text { Std. Error }\end{array}$ & $\begin{array}{c}\text { Standardized } \\
\text { Coefficients } \\
\text { Beta }\end{array}$ & t & Sig \\
\hline DP to KKD & 0,060 & 0,022 & 0,507 & 2,698 & 0,054 \\
BD to KKD & $-0,417$ & 0,078 & $-1,006$ & $-5,356$ & 0,006 \\
DP to PE & 0,007 & 0,000 & 0,567 & 3,825 & 0,031 \\
BD to PE & 0,425 & 0,093 & 0,673 & 4,579 & 0,020 \\
KKD to PE & 0,363 & 0,060 & 0,874 & 6,086 & 0,009 \\
\hline
\end{tabular}

Primary Data, 2019

Based on the results of the analysis in the table of the results of multiple linear regression analysis, the regression equation used in this study can be written as follows:

a) Effect of $\mathrm{DP}$ and $\mathrm{BD}$ on KKD:

$\mathrm{KKD}=0.060 \mathrm{DP}+-0.417 \mathrm{BD}+\varepsilon 1$

b) Effect of $\mathrm{DP}, \mathrm{BD}$, and KKD on PE:

$\mathrm{PE}=0.007 \mathrm{DP}+0.425 \mathrm{BD}+0.363 \mathrm{KKD}+\varepsilon 2$

The calculation of the Sobel test can be seen in the following Table 3:

Dilliana, S. M., Gayatri, G., Ratnadi, N. M. D., \& Wirajaya, I. G. A. (2019). Regional financial performance mediates the effect of regional balance funds and expenditures on economic growth. International Research Journal of Management, IT and Social Sciences, 6(6), 164-171. https://doi.org/10.21744/irjmis.v6n6.782 
Table 3

Indirect effect

\begin{tabular}{llll}
\hline & Path Coefficient & $\mathrm{Sp}_{1} \mathrm{p}_{5}$ & $\mathrm{t}_{1}$ \\
\hline $\mathrm{P}_{1}$ & 0,060 & 0,00006708 & 324,6869 \\
$\mathrm{P}_{5}$ & 0,363 & & \\
$\mathrm{Sp}_{1}$ & 0,022 & & \\
$\mathrm{Sp}_{5}$ & 0,060 & $\mathrm{Sp}_{2} \mathrm{p}_{5}$ & \\
& Path Coefficient & 0,00143748 & $\mathrm{t}_{2}$ \\
$\mathrm{P}_{2}$ & $-0,417$ & & $-105,3030$ \\
$\mathrm{P}_{5}$ & 0,363 & & \\
$\mathrm{Sp}_{2}$ & 0,078 & 0,0036 & \\
$\mathrm{Sp}_{5}$ & 0,060 & & \\
\hline
\end{tabular}

Primary Data, 2019

\section{Effects of Balancing Funds on Regional Financial Performance}

The result of the hypothesis one (H1) analysis states that the balanced fund does not affect regional financial performance. This result does not contribute to the stewardship theory. The balance funds received by the regional government in this case the Sikka Regency government have not been used to improve their performance so that the balance funds received by the regional governments increase or decrease cannot affect the regional financial performance. The results of this study are not in line with the results of research conducted by Sivagnanam \& Naganathan (1999); and Kuncoro (2007), which states that the increase in balancing funds significantly increases the acquisition of local revenue by looking at regional financial performance.

\section{Effects of Regional Expenditures on Regional Financial Performance}

Hypothesis 2 states that regional expenditure has a negative effect on regional financial performance. The results of this study were not able to contribute to the theory of stewardship. The allocation of indirect expenditure in Sikka Regency in 2012-2018 was higher than the direct expenditure allocation. This study is in line with research by Widiasih \& Gayatri (2017), who found that civil servant expenditure, honorary staff expenditure, goods, and services expenditure and capital expenditure did not influence the performance achievements of local government agencies where civil servant expenditure (indirect expenditure) was greater from direct expenditure allocations in Boyolali District (2010).

\section{Effects of Balancing Funds on Economic Growth}

Hypothesis 3 states that balanced funds have a positive effect on economic growth and the results of this study are able to contribute to the stewardship theory. In Sikka Regency, in 2012-2018 the number of general allocation funds and revenue sharing funds increased, so economic growth increased. Likewise with special allocation funds that have fluctuated but tend to increase, then economic growth also increases. The results of this study are in line with research conducted by Indarto \& Ayu (2011), which is the realization of central government spending in the region which has a positive effect on economic growth.

\section{Effects of Regional Expenditures on Economic Growth}

Hypothesis 4 states that regional expenditure has a positive effect on economic growth. The results of this study can contribute to the theory of stewardship. In Sikka Regency, infrastructure development has been carried out to encourage regional economic growth including sectors related to economic growth such as for the infrastructure sector such as the construction of highways and dam construction and for the education sector there are 86 school libraries building packages and school rehabilitation works. In the health services sector, there has been an increase in health services that have become more evenly distributed, with the development of puskesmas in several remote areas in Sikka Regency. Research conducted by Nuryani et al., (2018), proves that indirect and direct expenditure has a significant positive effect on economic growth. 


\section{Effects of Regional Financial Performance on Economic Growth.}

Hypothesis 5 states that regional financial performance has a positive effect on economic growth. The results of this study indicate that this research is able to contribute to the theory of stewardship. On average, the ratio of regional financial independence in Sikka District is at a ratio of 10.9\% from 2012-2018 in the very low category, because it is in the ratio of $0 \%-25 \%$. The effectiveness ratio on the average experienced the effectiveness of Sikka district's original revenue from 2012-2018 of $96.55 \%$ which was in the quite effective category. The ratio of regional financial efficiency is also known that the average financial efficiency of Sikka Regency from 2012 to 2018 was $97.21 \%$ or it can be said to be efficient. This research is in line with the research of Nisa (2017); Mahaputra \& Putra (2014); and Suryaningsih et al., (2015).

\section{The Effect of Balancing Funds on Economic Growth with Regional Financial Performance as a Mediating Variable}

Hypothesis 6 shows that regional financial performance is able to mediate the effect of balanced funds on economic growth. The results of this study indicate that this research is able to contribute to the theory of stewardship. This shows that the greater the balance of funds obtained by Sikka Regency, the greater the development of public infrastructure that can be done by local governments and reflects the level of the financial performance of local governments and can increase regional economic growth.

Effect of Regional Expenditures on Economic Growth with Regional Financial Performance as a Mediating Variable

Hypothesis 7 shows that regional financial performance is not able to mediate the effect of regional spending on economic growth. The results of this study indicate that this study was unable to contribute to the theory of stewardship. In Sikka Regency there has been an increase in the allocation of regional expenditure budget over the past 5 years but the local government has not been focused on the superior sectors in Sikka Regency such as the agriculture, forestry and fisheries sectors that have an active role in economic growth, causing these three leading sectors of Sikka Regency to gradually decreases.

\section{Conclusion}

The results of the study concluded are as follows: the balance fund does not affect the regional financial performance, regional expenditure negatively affects the regional financial performance, the balancing fund, regional expenditure and regional financial performance has a positive effect on economic growth, the ability of the regional financial performance mediates the balancing fund on economic growth and the inability of regional financial performance to mediate regional spending on economic growth.

\section{Suggestion}

The regional government is expected to allocate the funds in accordance with its goal of accelerating regional economic growth, it is hoped that the local government of Sikka Regency will consider the decisions taken in allocating the budget to suit the conditions and needs of the region so that it can optimize the use of the existing budget so that it is able to manage and fully utilize the profit-sharing funds, general allocation funds, and special allocation funds to improve the quality of public services through infrastructure development and are expected to use other proxies in addition to the independence ratio, effectiveness ratio and efficiency ratio in measuring the financial performance of local governments which include activity ratios, DSCR ratios, and growth ratios.

\section{Conflict of interest statement}

The authors declared that they have no competing interests.

Statement of authorship

The authors have a responsibility for the conception and design of the study. The authors have approved the final article.

Dilliana, S. M., Gayatri, G., Ratnadi, N. M. D., \& Wirajaya, I. G. A. (2019). Regional financial performance mediates the effect of regional balance funds and expenditures on economic growth. International Research Journal of Management, IT and Social Sciences, 6(6), 164-171. https://doi.org/10.21744/irjmis.v6n6.782 


\section{Acknowledgments}

The authors would like to thank the reviewer for their consideration of the further process of the present paper. Thanks to the editor of IRJMIS for the valuable support, time as well as advice. 


\section{References}

Astuti, W. (2015). Analisis pengaruh kinerja keuangan terhadap pertumbuhan ekonomi dan dampaknya terhadap pengangguran dan kemiskinan (studi pada Kabupaten dan Kota di Pulau Jawa periode 2007-2011). EBBANK, 6(1), $1-18$.

Donaldson, L., \& Davis, J. H. (1991). Stewardship theory or agency theory: CEO governance and shareholder returns. Australian Journal of management, 16(1), 49-64. https://doi.org/10.1177\%2F031289629101600103

Hadi, A., Handajani, L., \& Putra, I. N. N. A. (2018). Financial Disclosure based on Web-ICT Determinants: Its Implications for Local Government Financial Performance in Indonesia. International Research Journal of Management, IT and Social Sciences, 5(1), 72-85.

Indarto, S. L., \& Ayu, S. D. (2011). Pengaruh Partisipasi dalam Penyusunan Anggaran terhadap Kinerja Manajerial Perusahaan melalui Kecukupan Anggaran, Komitmen Organisasi, Komitmen Tujuan Anggaran, dan Job Relevant Information (JRI). Seri Kajian Ilmiah, 14(1), 1-22.

Kuncoro, M. (2007). Ekonomika industri Indonesia: menuju negara industri baru 2030?. Penerbit Andi.

Kusumawati, L., \& Wiksuana, I. G. B. (2018). Pengaruh Pendapatan Daerah terhadap Pertumbuhan Ekonomi di Wilayah Sarbagita Provinsi Bali. E-Jurnal Manajemen Universitas Udayana, 7(5).

Mahaputra, I. P. U. R., \& Putra, I. W. (2014). Analisis Faktor-Faktor yang Mempengaruhi Kualitas Informasi Laporan Keuangan Pemerintah Daerah. E-Jurnal Akuntansi, 230-244.

Mustikarini, W. A., \& Fitriasari, D. (2012). Pengaruh karakteristik pemerintah daerah dan temuan audit BPK terhadap kinerja pemerintah daerah kabupaten/kota di Indonesia tahun anggaran 2007. Simposium Nasional Akuntansi XV: Banjarmasin.

Nisa, A. A. (2017). Analisis Pengaruh Pendapatan Asli Daerah, Dana Alokasi Umum, dan Bagi Hasil Pajak Terhadap Pertumbuhan Ekonomi Kabupaten/Kota di Provinsi Jawa Timur. Jurnal Ilmu EKonomi JIE, 1(2), $203-214$.

Nuryani, N. N. J., Satrawan, D. P. R., Gorda, A. A. N. O. S., \& Martini, L. K. B. (2018). Influence of human capital, social capital, economic capital towards financial performance \& corporate social responsibility. International Journal of Social Sciences and Humanities, 2(2), 65-76. https://doi.org/10.29332/ijssh.v2n2.128

Pratini, P., \& Utama, I. W. M. (2016). Pengaruh Kepemimpinan Transformasional dan Budaya Organisasi Terhadap Motivasi dan Kinerja Karyawan. E-Jurnal Manajemen, 5(7).

Putong, I. (2013). Economics pengantar mikro dan makro. Jakarta: Mitra Wacana Media.

Sidik, M. (2002). Optimalisasi pajak daerah dan retribusi daerah dalam rangka meningkatkan kemampuan keuangan daerah. Makalah disampaikan Acara Orasi Ilmiah. Bandung, 10.

Sivagnanam, K. J., \& Naganathan, M. (1999). Federal Transfers and the Tax efforts of the States in India (No. 3208). University Library of Munich, Germany.

Suryaningsih, N. N., Utama, M. S., \& Yasa, I. M. (2015). Dampak Kinerja Keuangan Daerah Terhadap Kesejahteraan Masyarakat Kabupaten/Kota Di Provinsi Bali. E-Jurnal Ekonomi dan Bisnis Universitas Udayana, 4(2015), 537554.

Widiasih, N. N. \& Gayatri (2017). Pengaruh pendapatan asli daerah, dana alokasi umum, dan dana bagi hasil pada belanja modal. E-Jurnal Akuntansi, 2143-2171.

Dilliana, S. M., Gayatri, G., Ratnadi, N. M. D., \& Wirajaya, I. G. A. (2019). Regional financial performance mediates the effect of regional balance funds and expenditures on economic growth. International Research Journal of Management, IT and Social Sciences, 6(6), 164-171. https://doi.org/10.21744/irjmis.v6n6.782 